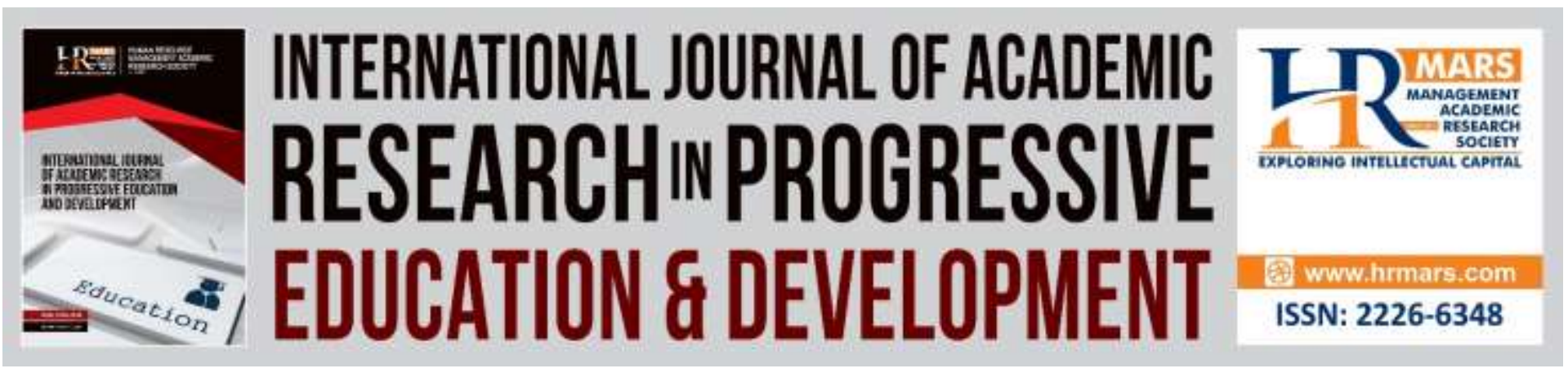

\title{
Motivational Factors Among Undergraduates Learning Mandarin: A Qualitative Perspective
}

\author{
K.M. Cheong, Z. Jano, S. Salam, N. Abdul Bareed, F. Ithnin, \\ N. Suraidi
}

To Link this Article: http://dx.doi.org/10.6007/IJARPED/v8-i2/5694

DOI: $10.6007 /$ IJARPED/v8-i2/5694

Received: 03 March 2019, Revised: 11 April 2019, Accepted: 21 April 2019

Published Online: 30 April 2019

In-Text Citation: (Cheong et al., 2019)

To Cite this Article: Cheong, K. M., Jano, Z., Salam, S., Bareed, N. A., Ithnin, F., \& Suraidi, N. (2019). Motivational Factors Among Undergraduates Learning Mandarin: A Qualitative Perspective. International Journal of Academic Research in Progressive Education and Development, 8(2), 187-199.

Copyright: (C) 2019 The Author(s)

Published by Human Resource Management Academic Research Society (www.hrmars.com)

This article is published under the Creative Commons Attribution (CC BY 4.0) license. Anyone may reproduce, distribute, translate and create derivative works of this article (for both commercial and non-commercial purposes), subject to full attribution to the original publication and authors. The full terms of this license may be seen at: http://creativecommons.org/licences/by/4.0/legalcode

Vol. 8(2) 2019, Pg. 187 - 199

http://hrmars.com/index.php/pages/detail/IJARPED

JOURNAL HOMEPAGE

Full Terms \& Conditions of access and use can be found at http://hrmars.com/index.php/pages/detail/publication-ethics 


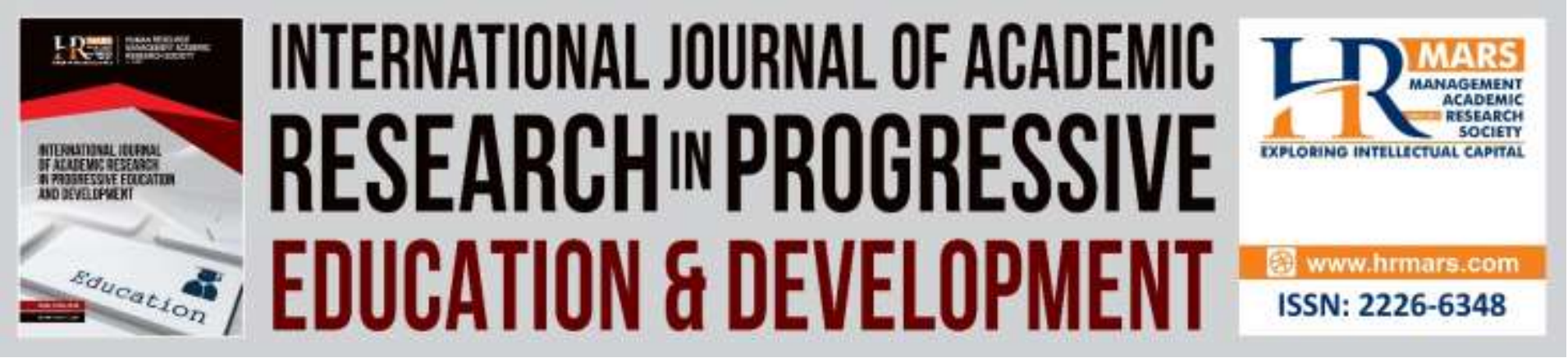

\title{
Motivational Factors Among Undergraduates Learning Mandarin: A Qualitative Perspective
}

\author{
K.M. Cheong, Z. Jano, S. Salam, N. Abdul Bareed, F. Ithnin, \\ N. Suraidi \\ Universiti Teknikal Malaysia Melaka, Hang Tuah Jaya, 76100 Durian Tunggal, Melaka, \\ Malaysia
}

\begin{abstract}
Mandarin is an important international language beside English. The purpose of this study was to investigate the motivation of undergraduate students learning Mandarin. A qualitative analysis through interview sessions was used in this study. Four undergraduate students participated in the interview and their transcripts were analyzed to ascertain common themes or categories. The findings showed that "to be ready for future career" and "to be able to communicate with Chinese friend" were two motivational factors for students learning Mandarin. This study is beneficial for Mandarin tutors and instructors in order to determine the content of Mandarin learning materials. In future, a similar study using a triangulation method should be conducted.
\end{abstract}

Keywords: Motivational Factors, Motivation, Undergraduate, Mandarin, Qualitative

\section{Introduction}

Mandarin is an important international language besides English, therefore in order to grab this business opportunity, people are driven to learn Mandarin. As Zubairi and Sarudin (2009) remarked, "in order to participate in the global economy, one has to be adequately equipped with the ability, knowledge, skills, and attitudes to understand and communicate effectively" (p.73). The Vice Chancellor of the University of Malaya, Professor Jasmon (2012) has indicated that University Malaya is striving to promote and support research on Chinese language to its academics. Besides, highly employable graduates with skills will be produced to benefit future companies.

Ghauth (2012) showed that in the world of global economy, Mandarin language has become a popular language and is gaining recognition worldwide including higher education institutions in Malaysia. However, Mandarin is the second language for non-Chinese learners. NonChinese learners will face difficulties learning Mandarin due to the distinct pronunciation and pictographic characters. The difference between Mandarin and other alphabetic languages, like Malay and English is that the challenge for learners whose native language is not closely related to Mandarin increases. For example, in Chinese character learning, Sung and Wu (2011) have listed three challenges which non-Chinese may face in learning Mandarin; The large number of characters 
to be acquired before becoming literate, the lack of correspondence between a character and its pronunciation and many characters with different meanings share the same sound.

As a result, the learners need to be motivated to counter the challenges. Motivation refers to internal strength which creates the desire and leads a learner to put an additional effort to continue learning Mandarin based on individual's planned goal. Several studies focus on effective ways to enhance motivation (i.e., Tan and Ooi, 2006; Tan, Hairul, \& Muhamad, 2008; Yuanfang, 2009; Zubairi and Sarudin, 2009; Hsieh, 2009 and Feng, 2010). Their studies have shown the significance of motivation in language learning. According to Maslow's (1987) hierarchy of needs theory, we need to understand what level of hierarchy a person is in if we want to motivate someone. If instructors can identify students' major motivational factors in learning Mandarin, then, effective enhancement can be created to keep the students motivated throughout the learning process.

This study is significant for its contribution towards practices among educators, knowing the motivational factors in learning is important because through effective means of motivation enhancement, learning is improved. It will also enable policy makers and administrators to make sound decisions. This study, hence, aimed to investigate the major factors that motivate undergraduates to learn Mandarin as a foreign language in Universiti Teknikal Malaysia Melaka (UTeM).

\section{Relevant scholarship}

Academic achievement is one of the dependent variables to measure learning. In a formal education, academic achievement is the main variable to evaluate whether the curriculum objective is achieved (Olatoye, Akintunde, \& Yakasi, 2010). Among all the variables, motivation is one of the most influential factors in the success of learning a second /foreign language (Gardner, 1985). Motivation has a powerful influence on learning and it is found to be important in improving academic achievement. Motivation is an important factor to be considered since the motivated learners will always be better than the unmotivated learners in their performance.

Culture could be a motivational factor for students learning Mandarin. Students study Mandarin because of their desire to be closer to the Chinese culture. Therefore, the use of culturalbased content will enable students to make a connection between Mandarin and Chinese culture and its community. This statement is supported by $\mathrm{Wu}$ (2010)'s findings that friendship and appreciation of culture are motivational factors of Chinese language learners. The role of teacher could be another motivational factor because a teacher can increase students' motivation in learning by allowing them to display their work, encourage them to be proud of themselves and celebrate success with them. Rewards in the form of praise or personal words of encouragement are sufficient enough to motivate the students. Teacher behaviour is believed to affect learners' learning outcome. Nasiru (2006), the General Manager at Cambridge Silicon radio, states that a good leader will create a conducive condition in order to bring success for people around him/ her. In the context of learning in a classroom, a teacher is a leader who can help learners attain high achievement by creating a conducive environment for learning. Heller and Sottile (1996) also agree 
that a teacher can play a significant role in motivating students to learn by incorporating hands-on learning and at the same time making learning enjoyable and satisfying.

Besides teachers, parents play an important role in the education of children. Thienhuong (2007) has claimed that parents are also among the motivating factors that motivate students to do better. Thienhuong (2007)'s statement has been supported by Rindone (1988). Rindone (1988) has examined the background of Navajo college graduates to identify the factors that contribute to their high educational attainment. The findings show that $45 \%$ of the respondents report that encouragement from their parents and other family members contributes to their high academic achievements.

According to Renchler (1992), 'School culture has a positive influence on student motivation if students and teachers function in a school culture where academic success and the motivation to learn is expected, respected, and rewarded.' (p.3). Hence, a well-defined school goal with regard to academic achievement is needed. This statement is supported by Heller and Sottile (1996) who has carried out a qualitative study to analyze student motivation. He has found that the social aspect of school is important. The motivation will increase if students feel socially fulfilled and have a sense of belonging in the classroom. Brunel (1999)'s results of Pearson correlation analyses have also indicated that students who perceive their class climate as emphasizing mastery are more likely to feel self-determined.

Learning condition is another motivational factor. Based on the process-oriented model by Dornyei and Otto (1998), a motivational condition must be created which involves setting the scene for the use of motivational strategies. This statement is in agreement with Good and Brophy's (1994) results that learning will only occur within a relaxed and supportive atmosphere. If a teacher can reduce classroom anxiety by making the learning context less stressful, students will benefit immensely. Developing effective peer relationship is important in a classroom. Heller and Sottile (1996) have also urged teachers to create a conducive environment to develop effective peer relationships through the implementation of group activities. A teacher can find out the topics which students like to learn and try to incorporate them into the curriculum because Wu (2010)'s findings show that increasing the number of students' preferences can raise the motivation of learners.

Kember, Ho and Hong (2008) analyzed the importance of establishing relevance in motivating students in learning using the interview method. The findings yielded that teaching the abstract theory alone is demotivating and one of the important elements to motivate students in learning is by establishing the relevance of learning. Kember et al., (2008) conclude that four main methods for establishing relevance are: showing how theory can be applied in practice, establishing relevance to local cases, relating material to everyday applications and finding applications in current newsworthy issues. Kember et al. (2008)'s view is supported by Wigfield who has been interviewed by Bembenutty (2012) on the topic of expectancy -value, motivation, and reading achievement. In the interview, Wigfield expressed that the students' intrinsic motivation will be increased if they see the relevance of their classroom activities and tasks to their 
life. It means students' intrinsic motivation were associated with their perceptions on how their teachers emphasized the relevance of learning to their real life. This findings showing how specific instructional practices (as perceived by students) relate to positive change in their motivations to read. (Bembenutty, 2012)

Yuanfang (2009) has carried out a research on foreign language learning motivation and learning achievement from a cross cultural perspective because she believes that foreign language learning motivation is closely associated with factors related to language policy, curriculum, and pedagogy. She found that Chinese university students are more instrumentally motivated than their Australian counterparts, while Australian university students are more integratively motivated than their Chinese counterparts in foreign language learning.

According to Ames and Archer (1988), how students engage in learning is related to the perceived goals of the learning environment. Students with intrinsic motivation will often have the goal to achieve (Shia, 1998). Zimmerman, Bandura and Martinez-Pons (1992) indicated that, 'personal goals play a key role in students' attainment of grades in school' (p. 673). Positive mindset through goal setting is another motivating factor to motivate students to learn Mandarin. Ames and Archer (1988) has indicated that 'mastery goal orientation will promote a motivational pattern likely to promote long-term and high-quality involvement in learning' (p. 263). This statement is in rhyme with Thienhuong (2007) and Meece, Anderman, and Anderman, (2006) studies as they also claim that the increase of goal orientation results in more effort and interest to accomplish something challenging in the subject domain; however, competition in the classroom should be monitored well in order to avoid negative consequences. (Lam, Yim, Law \& Cheung, 2004).

\section{Research Questions}

This study analyzed motivational factors of undergraduates learning Mandarin in one of Higher Learning Institutions in Malaysia in a qualitative perspective. This study utilized the following research questions.

R1: What are the major factors that motivate the undergraduates to learn Mandarin as a foreign language at UTeM?

R2:What is the relationships between Mandarin scores and the motivation in learning Mandarin as a foreign language?

\section{Methodology}

This section illustrates the site and setting, population samples, procedure and framework of analysis.

\section{Site and setting}

The present study was conducted in one of the public higher learning institutions in Melaka, Universiti Teknikal Malaysia Melaka (UTeM). The setting of this study is in a language classroom of Mandarin. 
INTERNATIONAL JOURNAL OF ACADEMIC RESEARCH IN PROGRESSIVE EDUCATION AND DEVELOPMENT

Vol. 8, No. 2, 2019, E-ISSN: 2226-6348 @ 2019 HRMARS

\section{Population and Sample Selection}

The first step in respondent selection is to define who will provide required data to answer the research question. Secondly, the researcher made sure that the respondents are easily accessible to her. Therefore, the researcher decided to confine her study to undergraduates in one of the government higher learning institution in Melaka. The respondents for this study was undergraduates learning Mandarin as a foreign language at Universiti Teknikal Malaysia Melaka. The respondents were students who registered for BLHL 1212 Mandarin I for a duration of 14 weeks in UTeM. Two male and two female students are chosen to be interviewed using purposeful sampling method.

\section{Procedure}

Prior to interview sessions, consent letters were given to the four informants. Paper, pencil and recorder were made available for the interview sessions which were conducted based on one to one and face-to-face basis. Each interview took between 10 and 15 minutes. The interview was conducted in English and transcribed. Each session was recorded and a full transcription was used for the analysis.

\section{Framework of data analysis}

Four interview sessions were conducted with four respondents on a one-to one basis for a duration of 10 to 15 minutes for each respondents. There was only one interview for each respondent. This decision made by researcher after discovering that there were no new insights or information as the information has already saturated. The interview was conducted in English. The assumption made in this study is the respondents understand the interview questions and answer the questions honestly and accurately. The reason for conducting interviews was to gain insights into respondents' motivational factors in learning Mandarin. Interview transcripts were read several times until the underlying patterns were gradually identified for establishing concept categorization. It was done by following the principle of common themes or categories. In this case, factors which motivated the students in their learning were the main focus of the analysis. The accuracy of data entry and codes were validated.

\section{Findings and Discussion}

\section{Demographic analysis of the respondents}

Based on the demographic data of respondents in Table 1, two male and two female respondents were selected as the respondents in the interview. They are students from Faculty of Technology management and Technopreneurship (FPTT) and Faculty of Information and Communication Technology (FTMK), aged between 22 and 26 years old. Three chosen respondents were Malay, and one was Bruneian Malay. 
INTERNATIONAL JOURNAL OF ACADEMIC RESEARCH IN PROGRESSIVE EDUCATION AND DEVELOPMENT

Vol. 8, No. 2, 2019, E-ISSN: $2226-6348$ @ 2019 HRMARS

Table 1: Demographic analysis of respondents

\begin{tabular}{|l|l|l|l|l|}
\hline Student & Gender & Race & Age & Faculty \\
\hline R1 & Male & Malay & 26 & FPTT \\
\hline R2 & Female & Malay & 22 & FPTT \\
\hline R3 & Male & Malay & 22 & FTMK \\
\hline R4 & Female & Brunei & 22 & FTMK \\
\hline
\end{tabular}

\section{Respondents' language Used in Daily Life}

According to Table 2 below, the three respondents R1, R2 and R3 reported that they did not have any experience in using mandarin in their daily lives. Three of them admitted that they would only use Malay while communicating with their family and friends, whereas, R4 admitted that she experienced using Mandarin in her daily life. "If my Chinese friends talk with me in Mandarin I will use a little bit of Mandarin (R4)"

Table 2: Language used by the respondents in the daily life

\begin{tabular}{|c|c|c|c|}
\hline Student & $\begin{array}{c}\text { Language } \\
\text { used } \\
\text { with friend }\end{array}$ & $\begin{array}{c}\text { Language } \\
\text { used } \\
\text { with family }\end{array}$ & $\begin{array}{c}\text { Experience } \\
\text { in } \\
\text { using } \\
\text { Mandarin }\end{array}$ \\
\hline R1 & Malay & Malay & No \\
\hline R2 & Malay & Malay & No \\
\hline R3 & Malay & Malay & Yes \\
\hline R4 & Malay/ Mandarin & Malay & \\
\hline
\end{tabular}

\section{Respondents' Attitude and their Reason in Learning Mandarin}

According to Table 3, all respondents reported that they liked and enjoyed learning Mandarin. "To be ready for future career" and "to be able to communicate with Chinese friends" were the two main reasons found through the interview with all the four respondents. This finding is similar to Cheong (2013) as she indicated that future occupation was a major motivational factor and friendship factor also ranked at three for students to learn Mandarin at UTeM. Tan and Ooi (2008) study also indicated that 'future occupation' was the strongest learning orientations among the students learning Mandarin at a public university in Malaysia. 
INTERNATIONAL JOURNAL OF ACADEMIC RESEARCH IN PROGRESSIVE EDUCATION AND DEVELOPMENT

Vol. 8, No. 2, 2019, E-ISSN: 2226-6348 @ 2019 HRMARS

Table 3: Students' attitude and their reason for learning Mandarin

\begin{tabular}{|c|l|l|}
\hline Student & \multicolumn{1}{|c|}{$\begin{array}{c}\text { Attitude of learning } \\
\text { Mandarin }\end{array}$} & \multicolumn{1}{c|}{$\begin{array}{c}\text { Reason for learning } \\
\text { Mandarin }\end{array}$} \\
\hline R1 & $\begin{array}{l}\text { I enjoy learning Mandarin because it } \\
\text { is the third language I want to learn. }\end{array}$ & $\begin{array}{l}\text { Because Mandarin is needed in the } \\
\text { workplace nowadays }\end{array}$ \\
\hline R2 & I like learning Mandarin. & $\begin{array}{l}\text { When our Chinese friends are talking in } \\
\text { Mandarin, we will know what they are } \\
\text { talking about. Nowadays, there is a need of } \\
\text { Mandarin in the workplace besides English. }\end{array}$ \\
\hline R3 & $\begin{array}{l}\text { I like and enjoy learning Mandarin. I } \\
\text { learn how to greet people and use } \\
\text { simple language like what is your } \\
\text { favourite food. }\end{array}$ & $\begin{array}{l}\text { In Malaysia there are Chinese, I want to } \\
\text { learn their language. }\end{array}$ \\
\hline R4 & $\begin{array}{l}\text { I enjoy learning Mandarin } \\
\text { and }\end{array}$ & $\begin{array}{l}\text { Because I have some knowledge in } \\
\text { Mandarin, I want to improve my Mandarin } \\
\text { language. Mandarin is a very interesting } \\
\text { language. Many jobs put Mandarin } \\
\text { language as one of their requirements, it } \\
\text { will be an additional bonus if we know } \\
\text { Mandarin. }\end{array}$ \\
\hline
\end{tabular}

Respondents' Understanding of Motivation and their Perception on the Importance of Motivation in Learning Mandarin

Table 4 shows students' insights on definition and importance of motivation in learning Mandarin. All the respondents understand well the definition of motivation. Hence, this is important to ensure the correctness and validity of their information. 
INTERNATIONAL JOURNAL OF ACADEMIC RESEARCH IN PROGRESSIVE EDUCATION AND DEVELOPMENT

Vol. 8, No. 2, 2019, E-ISSN: $2226-6348$ @ 2019 HRMARS

Table 4: Students' perception on definition and importance of motivation

\begin{tabular}{|c|c|c|}
\hline Student & $\begin{array}{l}\text { Student's } \\
\text { definition of } \\
\text { motivation }\end{array}$ & $\begin{array}{l}\text { Perception on the importance of motivation in learning } \\
\text { Mandarin }\end{array}$ \\
\hline R1 & $\begin{array}{l}\text { Eager to learn } \\
\text { something }\end{array}$ & $\begin{array}{l}\text { If the student does not have motivation, he/she has no } \\
\text { enthusiasm for learning }\end{array}$ \\
\hline $\mathrm{R} 2$ & encourager & Motivation is important in learning. \\
\hline R3 & $\begin{array}{l}\text { We have the urge } \\
\text { to learn } \\
\text { something new }\end{array}$ & $\begin{array}{l}\text { Mandarin is quite difficult to learn but for someone who } \\
\text { has motivation, learning Mandarin will be easier. }\end{array}$ \\
\hline R4 & $\begin{array}{l}\text { One thing that } \\
\text { drives us to } \\
\text { achieve our } \\
\text { objectives }\end{array}$ & Motivation is very important in learning Mandarin \\
\hline
\end{tabular}

The respondents are found to have a strong determination and positive attitude towards learning Mandarin. They value the importance of motivation in learning Mandarin. With their readiness, they are predicted to learn well in Mandarin. It is supported by the law of readiness which indicated that if the students have positive perception towards learning and are ready to go for it, they will be able to achieve better results in that field.

The Relationship between Respondents' Motivation and their Achievement in Mandarin. All the respondents strongly agreed that there was a positive correlation between motivation and the effectiveness in Mandarin learning. The marks scored by the respondents in the exam after the interview was used to correlate to their justifications. Table 5 shows that there was really a positive correlation between students' motivation and marks scored in Mandarin.

Table 5: The relationship between students' motivation and their achievement in Mandarin

\begin{tabular}{|c|c|c|}
\hline Student & Student's motivation in learning Mandarin & Mandarin scores \\
\hline R1 & $\begin{array}{l}\text { I have no motivation in learning Mandarin because there are } \\
\text { many students in the class, so the lecturer cannot focus on } \\
\text { every student. I often sit at the back, I cannot understand } \\
\text { what is taught by the lecturer. }\end{array}$ & 40 marks \\
\hline $\mathrm{R} 2$ & I have little motivation in learning Mandarin & 47 marks \\
\hline R3 & $\begin{array}{l}\text { I have motivation in learning. Sometimes, I feel sad and } \\
\text { want to give up, but then the feeling of wanting to learn } \\
\text { Mandarin so I can have conversations with Chinese friends } \\
\text { keeps me learning Mandarin. }\end{array}$ & 70 marks \\
\hline R4 & Yes, I have motivation in learning Mandarin & 80 marks \\
\hline
\end{tabular}


The marks scored by the respondent depended strongly on their motivational level and motivational factors. As R1 admitted that he did not have any motivation in learning Mandarin, his leaning is not driven by motivational factor of intrinsic value and self development because he reported that, "I often sitting at the back ,I cannot get what is taught by the lecturer." and as a result he only score 40 marks in Mandarin which is the lowest among the four respondents interviewed. R2 reported that she only has little motivation in learning Mandarin, as a result she only achieve 47 marks in the exam. In contrast, the higher achievers among the four respondents who are R3 and R4 reported to have motivation in learning Mandarin, and as a result they scored a better result which is 70 marks and 80 marks in Mandarin. This finding showed there was really a positive correlation between students' motivation level or factor and marks scored in Mandarin. This finding is similar to Cheong (2015) who indicated that there was a significant relationship between Mandarin scores and all six motivational factors. Among all six motivational factors, one of them was intrinsic value and self-development which is best described the scenario happened to R1. Another motivational factor which is mentioned by Cheong (2015) could best explain the successful case of R3 who is driven by motivational factor of friendship in learning Mandarin.

Respondents Opinion on Increasing The Strength of Motivational Factor In Learning Mandarin According to Table 6 below, respondents have given their opinion on increasing the strength of motivational factor in learning Mandarin.

Table 6: Students' opinion on the strength of motivational factor in learning Mandarin

\begin{tabular}{|l|l|}
\hline Student & Student's opinion on increasing the strength of motivational factor \\
\hline R1 & $\begin{array}{l}\text { 1. Has a small classroom setting. } \\
\text { 2. Ensure good communication between lecturer and students. }\end{array}$ \\
\hline R2 & $\begin{array}{l}\text { 1. Desire to interact with friends. } \\
\text { 1.Enhance communication skills to socialize with friends of Mandarin } \\
\text { speaking group. } \\
\text { 2. Desire to learn new language. }\end{array}$ \\
\hline R4 & $\begin{array}{l}\text { 1. Use Mandarin for future use such as getting a job. } \\
\text { 2.Socialize. } \\
\text { 3.Parent's influence }\end{array}$ \\
\hline
\end{tabular}

Learning environment can be one of the motivational factors. R1 who was reported earlier that he do not have any motivation in learning Mandarin due to uncomfortable learning environment. He believed that small group learning would foster learning in the classroom. R1 believe learning condition is another motivational factor. R1's concern is in agreement with Good and Brophy's (1994) results that learning will only occur within a relaxed and supportive atmosphere. Based on the process-oriented model by Dornyei and Otto (1998), a motivational condition must be created which involves setting the scene for the use of motivational strategies. Besides, R1 also believe sufficient communication between lecturer and students would foster learning in the classroom. Heller and Sottile (1996) have also urged teachers to create a conducive 
environment to develop effective peer relationships through the implementation of group activities. If a teacher can reduce classroom anxiety by making the learning context less stressful, students will benefit immensely.(Good \& Brophy, 1994).

All three respondents R2, R3 and R4 have reported to have desire to socialize with friends using Mandarin. Wu (2010) also agreed that friendship and appreciation of culture are motivational factors of Chinese language learners. As suggested by R2, 'enhancing communication skill' could be a driving force to make their desire become a reality.

Besides, intrinsic motivation as suggested by R3 which is 'desire to learn new thing' would also be a motivational factor that would drive a student to learn Mandarin. A teacher can find out the topics which students like to learn and try to incorporate them into the curriculum because $\mathrm{Wu}$ (2010)'s findings show that increasing the number of students' preferences can raise the motivation of learners. Heller and Sottile (1996) also agree that a teacher can play a significant role in motivating students to learn by incorporating hands-on learning and at the same time making learning enjoyable and satisfying.

Parent's influence would also be a motivational factor that would drive a student to learn Mandarin. R4 has reported that she is encouraged by her parents to learn mandarin. It is similar to Hoang (2007) and Rindone (1988) study which claimed that parents are also one of the motivating factors that motivate students to do better.

\section{Respondents' Suggestion On The Role Played By Teacher On Motivating Student In Learning Mandarin}

According to Table 7 below, both teacher and students need to play an important role in the classroom. As suggested by the respondents, the teacher should play the role in determining the teaching materials according to Taxonomy Bloom, involve students in interactive activities and use audio visual elements as the methods of lecture delivery. In addition, students' commitment towards learning is also very important.

\section{Table 7: Students' suggestions on the role played by teacher on motivating students in learning} Mandarin

\begin{tabular}{|l|l|}
\hline Student & \begin{tabular}{l} 
Suggestions on motivating students in learning Mandarin \\
\hline R1
\end{tabular} \\
\hline R2 & $\begin{array}{l}\text { 1. Teacher organizes activities in the classroom so that students can participate. } \\
\text { 2. Teacher assigns project of oral speaking which allows students to speak in front of audience. }\end{array}$ \\
\hline R3 & $\begin{array}{l}\text { 1. Teacher has to give confidence to students. } \\
\text { 3. Teacher should arrange the learning sequence from basic to difficult. }\end{array}$ \\
\hline R4 & $\begin{array}{l}\text { 1. Teacher should implement video audio in learning. } \\
\text { 2. Teacher should increase activities such as presentation and role play. } \\
\text { students. } \\
\text { 3.Teacher must encourage students to speak Mandarin in the class. }\end{array}$ \\
\hline
\end{tabular}


INTERNATIONAL JOURNAL OF ACADEMIC RESEARCH IN PROGRESSIVE EDUCATION AND DEVELOPMENT

Vol. 8, No. 2, 2019, E-ISSN: 2226-6348 @ 2019 HRMARS

\section{Conclusion}

In conclusion, the findings show that generally all the respondents have a positive attitude towards learning Mandarin. The findings show a significant relationship between Mandarin scores and the motivation. "To be ready for future career" and "to be able to communicate with Chinese friend" are the two main motivational factors in learning Mandarin. The respondents suggest that both teacher and students need to play important roles in the classroom. The teacher should also play the role in determining the teaching material according to Taxonomy Bloom, involving students in interactive activities and using audio visual elements as the methods of lecture delivery. In addition, students' commitment towards learning is also very important. This study is beneficial for Mandarin tutors and instructors in order to determine the content of Mandarin learning materials. In future, more research in different variables should be considered in order to find the motivational factors of students learning mandarin.

\section{References}

Zubairi, A. M., \& Sarudin, I. (2009). Motivation to learn a foreign language in Malaysia. GEMA Online Journal of Language Studies, 9(2), 73-87.

Ames, C. \& Archer, J. (1988). Achievement goals in the classroom: Students' learning strategies and motivation Processes. Journal of Educational Psychology, 80(3), 260-269.

Bembenutty, H. (2012). An interview with Allan Wigfield: A giant on research on expectancyvalue, motivation, and reading achievement. Journal of Advance Academics, 23(2), 185193.

Cheong, K. M., Zanariah, J., Aziz, Y., \& Hanipah, H. (2013). The motivational factors among undergraduates learning Mandarin in a higher education institution. Scottish Journal of Arts, Social Sciences and Scientific Studies, 17(1), 79-87.

Cheong, K. M., Zanariah, J., \& Hanipah, H. (2015). The Relationship Between Motivational Factors And Mandarin Performances In A Higher Education Institution. Asian Social Science, 11(17), 1-8.

Dornyei, Z. \& Otto, I. (1998). Motivation in action: A process model of L2 motivation. In Working Papers in Applied Linguitics, Thames Valley University, 4, 43-69.

Feng, C. H. (2010). A correlational study of language learning motivation and strategies of Chinese undergraduate. Canadian Social Science, 6(4), 202-209.

Gardner, R. (1985). Social psychology and second language leaning: The role of attitudes and motivation. London: Edward Arnold.

Ghauth, J. (2012). International Chinese Language Conference 2012. Kuala Lumpur: University of Malaya

Good, T. \& Brophy, J. (1994). Looking in the classroom. (6 ${ }^{\text {th }}$ ed.). New York: Harper

Heller, D. \& Sottile, Jr, J. M. (1996). Another look at student motivation: a qualitative study. Marshall University.

Hsieh, C. N. (2009). L2 learners' self-appraisal of motivational changes over time. Issues in Applied Linguistics, 17(1), 3-26.

Kember, D., Ho, A. \& Hong, C. (2008). The importance of establishing relevance in motivating student learning. Active learning in higher education, 9(3), 249-263. 
INTERNATIONAL JOURNAL OF ACADEMIC RESEARCH IN PROGRESSIVE EDUCATION AND

DEVELOPMENT

Vol. 8, No. 2, 2019, E-ISSN: 2226-6348 @ 2019 HRMARS

Sung, K. Y., \& Wu, H. P. (2011). Factors influencing the learning of Chinese characters. International Journal of Bilingual Education and Bilingualism, 14(6), 683-700.

Lam, S. F., Yim, P. S., Law, J. S., \& Cheung, R. W. (2004). The effects of competition on achievement motivation in Chinese classrooms. British Journal of Educational Psychology, 74(2), 281-296.

Maslow, A. H. (1987). Motivation and personality. New York: Harper \& Row.

Meece, J. L., Anderman, E. M. \& Anderman, L. H. (2006). Classroom goal structure, student motivation, and academic achievement. Annual Review of psychology, 57, 487-503.

Nasiru, M. (2006). The Hindu Business Line: leader speech motivating leaders, Don't honk! 11.

Olatoye, R. A., Akintunde, S. O., \& Yakasi, M. I. (2010). Emotional intelligence, creativity, and academic achievement of Business Administration students.

Renchler, R. S. (1992). Student motivation, school culture, and academic achievement: What school leaders can do. ERIC Clearinghouse on Educational Management.

Rindone, P. (1988). Achievement motivation and academic achievement of native American student. Jounal of American Indian Education, 28(1).

Shia, R. M. (1998). Assessing academic intrinsic motivation: A look at student goals and personal strategy. Unpublished college thesis, Wheeling Jesuit University, Wheeling, WV. Retrieved February, 17, 2003

Tan, T. G., \& Ooi, A. K. (2006). Motivation of Malay students towards learning Mandarin as a foreign language. In Proceedings paper of the second CLS international conference (CLaSIC) 2006. National University of Singapore.

Tan, T. G., Hairul, N. I. \& Muhamad, K. K. A. (2008), Motivational factors of Malay students learning Mandarin: An exploratory study. Universiti Sains Malaysia.

Hoang, T. (2007). Creativity: A motivational tool for interest and conceptual understanding in science education. International Journal of Human and Social Sciences, 2(8), 477-483.

Wu, M. F. (2010). An Exploratory Study of the Language-learning Preferences and languageLearning Motivation of ESL Learners at a Vocational Education Institut in Hong Kong. Electronic Journal of Foreign Language Teaching, 7(1), 222-238.

Yuanfang, Y. (2009). A study of foreign language learning motivation and achievement: from a perspective of sociocultural theory. CELEA Journal, 32(3), 87-97.

Zimmerman, B. J, Bandura, A. \& Martinez-Pons, M.(1992). Self-motivation for academic attainment: the role of self-efficacy beliefs and personal goal setting. American Educational Research Journal, 29(3), 663-676.

\section{Acknowledgement}

Special thanks to Universiti Teknikal Malaysia Melaka that has funded the study.

\section{Corresponding Author}

Zanariah Jano, Universiti Teknikal Malaysia Melaka, Malaysia, zanariahjano@utem.edu.my 